state control. ${ }^{30}$ Thus the decision clears the way for recurrence of the very industry practices which led the federal government to assert antitrust jurisdiction. If the $\mathrm{McC}$ arran Act lends itself to the construction placed upon it by the court, that statute stands in need of legislative clarification and strengthening. ${ }^{31}$

\title{
TAXATION OF DEFERRED COMPENSATION: SOME MODEST PROPOSALS
}

AN employee who desires to assure himself and his survivors of some degree of economic security following his retirement or death has several courses available. He may purchase an annuity to provide income during his retirement, or life insurance to provide for his survivors. If he wishes to cover both needs, he may purchase an endowment policy. ${ }^{1}$ Premiums for any of these policies ordinarily come from income which has been taxed. But if the employee has sufficient bargaining power with his employer, he can, by the device of "deferred compensation," make equivalent provision for the future and avoid taxes as well.

30. Because of the holding in this case and the novelty of the problem, there is no judicial determination of what constitutes adequate state supervision of insurance rate making for McCarran Act purposes. Aside from the requirements of an adequate, competent staff and sufficient funds, and the controversial "pure-premium" problem, see note 26 supra, the following has been suggested: 1) advance approval or disapproval of those rates susceptible to that treatment, 2) approval or disapproval within a reasonable time after filing of those rates which are susceptible to that treatment, 3) the right to require filing and, thereafter, the right to approve or disapprove in those myriads of transactions where routine filing and approval are impractical. Dineen, The Rating Problem, ProceEdings of the Section of Insurance Law, American Bar Association 105, 110 (1945). See also the criteria suggested in Note, State Regulation of the Insurance Business and the Sherman Anti-trust Act, 96 U. of PA. L. REv. 223, 229 (1947).

31. It must be kept in mind that while a desire for federal regulation of insurance was disavowed at the time of the McCarran Act's passage, see 91 Cong. REc. 482 (1945); Joint Hearings Before Subcommittees of Committee on the Judiciary on S. 1362, H.R. 3269, and H.R. 3270, 78th Cong. 1st \& 2d Sess., Pt. 6, 637-40 (1943-4), such regulation is within Congress' competence to enact and may be precipitated by decisions whittling away state supervision of private rate-making combinations.

1. Life insurance, annuities, and endowments are three generic forms of personal insurance. All three provide for a money payment, either in a lump sum or in installments, at or beginning on a specified date. A life insurance policy matures at the death of the policyholder. An annuity matures at whatever date the policyholder chooses (the earlier the date, the higher the premium). An endowment combines life insurance with an annuity, maturing at death or at a specified date, whichever occurs earlier. Failure to continue paying life insurance premiums results in the forfeiture of premiums already paid, unless the policy has a cash surrender value. Failure to continue paying annuity or endowment premiums results in no more than partial forfeiture.

2. For a discussion of deferred compensation agreements, see Blodgett, Deferred 
Deferred compensation is just what the term implies-the postponement of the receipt of earned income. Here is a typical example: Mr. Jones enters into an eight-year employment contract. In return for his services, he is to receive $\$ 35,000$ annually. $\mathrm{He}$ is also to receive-and this is the deferred compensation- $\$ 35,000$ a year for 10 years after his employment ends. If he dies following his period of employment but prior to the receipt of all payments due, a named beneficiary will receive the remaining payments. Furthermore, if he dies during his period of employment a named beneficiary will receive ten annual $\$ 35,000$ payments. In effect, therefore, $\mathrm{Mr}$. Jones' compensation includes not only an annual salary, but also the same sort of protection which would be provided by a commercial endowment. ${ }^{3}$

If $\mathrm{Mr}$. Jones bargained for a higher annual salary in place of the deferred compensation, the additional sum would be liable to heavy surtaxes. ${ }^{4}$ If Mr. Jones' deferred compensation agreement required the employer to fund the plan through a trust, Mr. Jones would have to include contributions by the employer in his own gross income for the taxable year in which they were paid, unless his right to the contributions, at the time they were made, was forfeitable. ${ }^{5}$ The same would be true if the employer's contributions went

Compensation of Executives, 6 N.Y.U. Instrtute on FederaL Taxation 764 (1948); Blodgett, Recent Developments Concerning Deferred Compensation Plans, 7 N.Y.U. InstITUTE oN Federal Taxation 1093 (1949); Ahern, Aiding Top Executives to Make Advantageous Deferred Compensation and Business Expense Arrangements, 7 N.Y.U. INSTITUTE ON FEDERAL Taxation 858 (1949); Eisenstein, A Case of Deferred Compensation, 4 TAX L. REv. 391 (1949).

3. This hypothetical example is suggested by the contracts reprinted in May $D$. Hatch, 14 T.C. 237, 238-9 (1950) and Flarsheim v. United States, 156 F.2d 105 n.1 (8th Cir. 1946).

4. INT. REv. CoDE $\S 22(\mathrm{a})$ and $\S 12$.

5. INT. REv. CODE $\$ 165$ (c). By forfeitability is meant some "contingency under the plan which may cause the employee to lose his rights in the contribution," for example a requirement that the employee still be in the employ of the contributor at the time payments fall due. U.S. Treas. Reg. 111, \$\$ 29.165-7 (1943).

Section $165(\mathrm{c})$ is inapplicable, however, if the deferred compensation agreement is part of a plan which qualifies under Section $165(\mathrm{a})$. It is specifically provided that the beneficiary of such a plan is not chargeable with taxable income until he actually receives payments. INT. REv. Cone $\$ 165$ (b). However, a Section 165 (a) plan will seldom be available to a high salaried employee unless his employer is willing to set up a similar plan for a large number of his employees; and the plan cannot discriminate between high salaried and low salaried employees. INx. Rev. Cone $\$ \S 165(\mathrm{a}),(3),(4),(5)$, and (6). It is also noteworthy that even under a Section 165 (a) plan the employee is immediately chargeable with any money set aside by his employer to provide him with life insurance protection. U.S. Treas. Reg. 111, $\$ \$ 29.165-6$ (1943).

One court has held that when the right to the deferred compensation becomes nonforfeitable, the entire value of the right then vesting becomes taxable. $K$. R. Kingsbury, 31 B.T.A. 1126 (1935). This holding can be avoided by making payments contingent upon some such service as availability for consultation. The Treasury has never pressed the Kingsbury decision, perhaps because the Senate Finance Committee in 1942 specifically rejected a proposal by the House Ways and Means Committee which would have codified the holding of the Kingsbury case. SEN. Rep. No. 1631, 77th Cong., 2d Sess. 138 (1942); H.R. ReP. No. 2333, 77th Cong., 2d Sess. 104-5 (1942). 
directly toward the purchase of insurance instead of into a trust. ${ }^{6}$ But if a deferred compensation agreement of the sort outlined above is used, with no arrangement for funding and with the employee's right to future payments forfeitable it is generally contended that the additional compensation is not taxable income until it is actually received ${ }^{7}$ by the employee or his beneficiary. ${ }^{8}$

Apparently, then, by bargaining for a deferred compensation contract an employee can postpone the taxation of the additional income until after his retirement, when he has little, if any, other income. Furthermore, where some of the payments may be received by a survivor, a wife for example, it is likely that the survivor will have little other taxable income. And if the post-employment compensation period is made longer than the period of employment, the taxation of the additional income can be spread over a longer period of time.

Full use of existing law could close this tax loophole. When faced with a contract like Mr. Jones', the Treasury and courts could treat it just as if the employer had agreed to pay premiums on a commercial insurance policy for the employee. ${ }^{9}$ The Commissioner could determine what sort of insur-

6. Annuity premiums paid by the employer are so taxable unless part of a plan which meets the requirements of Sections $165(\mathrm{a}),(3),(4),(5)$, and (6) of the Code, see note 5 supra, or unless the employer is a charitable organization as defined in Section 101(6) of the Code. Int. Rev. Code $\$ 22$ (b)(2)(B). Life insurance premiums paid by the employer have long been held taxable to the employee, O.D. 627, 3 Curr. Burl. 104 (1920), although an exception is made for employer contributions to group life insurance. U.S. Treas. Reg. 111, $\$ 29.22(\mathrm{a})-3$ (1943). note 2 .

7. See the articles by Blodgett and Ahern, supra note 2. But cf. Eisenstein, supra

8. When the employee dies, the income taxation of payments received by his beneficiary seems to vary, depending on whether the value of the payments to be received by the beneficiary has been included in the deceased employee's gross estate. Where no estate tax had been levied, the Treasury has successfully attempted to tax the beneficiary on all amounts received under the contract. Flarsheim v. United States, 156 F.2d 105 (8th Cir. 1946). Where an estate tax had been levied, the Commissioner was successful in taxing amounts received by the beneficiary in excess of the estate tax valuation. May D. Hatch, 14 T.C. 237 (1950). Why an estate tax was levied in one case and not in the other is unclear. See 5 CCH 1950 FED. TAX. REP. $\$ 8670$.

More consistent treatment could be attained through the application of Section 126(a) of the Code, which allows as yet uncollected income "in respect of a decedent" to be taxed in the hands of whoever receives it. Deductions are allowed under a special statutory formula to the extent that the amounts received increased the tax levied on the decedent's estate. INT. REv. CODE $\$ 126(\mathrm{c})$. It is uncertain, however, whether the Treasury will attempt to apply Section 126 to deferred compensation contracts, or whether an attempted use would be sustained by the courts, since Section 126 was enacted by Congress for purposes wholly distinct from taxation of deferred compensation. See the statement of Randolph Paul, Hearings before Committee on Ways and Means on Revenue Revision of 1942, 77th Cong., 2d Sess. 89 (1942). See also, Hearings before Senate Finance Commiltee on H.R. 7378, 77 th Cong., 2d Sess. 71-4 (1942). The wording of Section 126 is, however, compatible with its application to deferred compensation contracts, and there would seem to be nothing inequitable in so applying it.

9. See note 6 supra. 
ance arrangement the deferred compensation resembles. Then he could determine, from actuarial tables, the yearly cost to the employee of a commercial policy paying benefits identical to those provided by the deferred compensation agreement. ${ }^{10}$ It could be assumed that the premium payments on such insurance would be spread over the number of years for which the employee contracted to perform services. The yearly costs so determined could be added to the employee's gross income for the corresponding year of his employment. ${ }^{11}$ Thus the taxation of the deferred compensation would be spread over the period of employment, just as would be done if the employee had bargained for a higher annual salary instead of for deferred compansation.

This method of closing the deferred compensation loophole could be justified by the fiction of constructive receipt. ${ }^{12}$ This fiction, which has the same tax consequences as actual receipt, is used by courts to prevent taxpayers from reducing their tax liability by postponing or transferring receipt of income. ${ }^{13}$ There should be no doubt, therefore, that constructive receipt is an appropriate tool for dealing with deferred compensation contracts. However, courts have tended to apply this doctrine sparingly. ${ }^{14}$ Various qualifications of it have been developed to protect the taxpayer from being taxed on income he may never receive. At first glance, it appears that deferred compensation agreements come within one or more of these qualifications. But closer examination reveals that these safeguards should protect an employee who avoids taxes through deferred compensation only when there is real danger that he will never receive the postponed income.

For example, application of constructive receipt sometimes depends on whether the taxpayer has an unqualified opportunity to reduce the postponed receipts to possession. ${ }^{15}$ But in the case of a deferred compensation agreement, the employee very likely had such an opportunity. Mr. Jones, for example, could have bargained for a higher annual salary during his period of employment had he not, in order to reduce surtaxes, arranged for

10. In cases where life insurance protection is provided by the deferred compensation plan, the life expectancy of the employee would be the crucial factor in determining this cost. ". . . [T]he method usually adopted of determining the present value of future contingent interests in property by the use of mortality tables is . . . well recognized." Guaranty Trust Co., 15 B.T.A. 20, 24 (1929). Peculiar circumstances with respect to life expectancy can also be taken into account. Ibid.

Although some courts have refused to recognize any necessary relation between actuarial tables and non-commercial insurance arrangements, an exception is made where the property to be valued cannot be valued without the use of such tables. Steinbach Kresge Co. v. Sturges, 33 F. Supp. 897, 900 (D. N.J. 1940).

11. Payments received by the distributee of the deferred compensation agreement should then be treated as if they were amounts received under a comparable insurance policy. See INT. Rev. CoDE $\$ \S 22(\mathrm{~b})(1), 22(\mathrm{~b})(2)$.

12. One authority suggests that the necessity of closing tax loopholes is sufficient justification. See Eisenstein, supra note 2.

13. See, e.g., Loose v. United States, 74 F.2d 147, 150 (8th Cir. 1934).

14. See, e.g., Wm. A. Hines, 38 B.T.A. 1061, 1067 (1938).

15. See, e.g., Avery v. Commissioner of Internal Revenue, 292 U.S. 210, 215 (1934). 
additional compensation to be paid him after his contractual obligations had been completely fulfilled. ${ }^{16}$

Courts have also refused to tax the employee where his right to the postponed receipts is forfeitable, for example where it is conditioned on continued employment. ${ }^{17}$ However, such a condition may well be a mere formality in the case of a high salaried executive who makes a deferred compensation agreement. Other conditions, such as covenants not to compete and availability for consultation, may be equally formal. In fact, they are frequently placed in deferred compensation contracts for the sole purpose of avoiding the possible application of constructive receipt. ${ }^{18}$

Nor should courts' reluctance to apply constructive receipt where the amounts due the taxpayer are indefinite ${ }^{19} \mathrm{keep}$ courts from taxing deferred compensation during years of active employment. For even if the amount of deferred compensation is indefinite, being based, for example, on a percentage of future profits, the uncertainty is of the taxpayer's own choice. ${ }^{2 n}$

16. Although this line of reasoning might seem to warrant the conclusion that instalment sellers should be taxable on the full sale price of all goods sold during a taxable year, no such implication is intended. Instalment sales require constant supervision until all payments are made. One who enters into a deferred compensation agreement collects his deferred compensation after his work has been completely performed. See INT. REV. CODE $\$ 44$.

17. Julian Robertson, 6 T.C. 1060 (1946). The employer in the Robertson case was obligated to contribute $\$ 12,500$ yearly to a trust. Since severance from employment was the only condition of the agreement which endangered the ultimate receipt of the deferred compensation, this case is perhaps the biggest stumbling block to taxation of deferred compensation. See also, U.S. Treas. Reg. 111, § 29.165-7 (1943); Harold G. Perkins, 8 T.C. 1051, 1056 (1947).

18. "To protect against [vesting], however, it has been deemed prudent to insert some provision marking the pension payments contingent upon availability for consultation, refraining from competition, availability of earnings, or some other reasonable contingency." Ahern, supra note 2, at 868-9.

Of course, such conditions may be enforced by the employer or even suggested by him. However, it is doubtful that any of the deferred compensation will be meant as compensation for meeting these conditions.

19. Walter I. Bones, 4 T.C. 415 (1944) (petitioner taxpayer refused to accept a check for commissions due him, since the check was offered on condition that it represent full payment of a disputed claim); W. A. Graeper, 27 B.T.A. 632 (1933) (rental terms not settled during first taxable year of lease, and rent for that period therefore not collected until subsequent taxable year). Additional cases are cited in 2 MERTENS, LAW of Federal INCOME TAXATION $\S 10.04$, n. 39 (1942).

20. A deferred compensation agreement which is tied to future profits is unlikely to be used for tax avoidance purposes unless the contracting parties have some idea of what those future profits will be, or unless a closely held concern is involved. Therefore, the Treasury should not apply the suggested approach to such contracts unless the case is obviously one of tax avoidance or unless the payments due under the contract can be forecast with reasonable accuracy.

The difficulties of forecasting the future payments will be greatly minimized if the contract provides upper or lower limits for the payments. But even in the absence of such limits, the valuation problem presented is no more difficult than similar problems which arise in other fields of tax law. See, e.g., Mathilde B. Hooper, 41 B.T.A. 114, 127-130 (1940). 
Moreover, unlike those situations in which the indefiniteness test has been invoked, ${ }^{21}$ deferred compensation agreements may be conscious attempts to avoid taxes.

A final qualification, uncertainty of ultimate payment, ${ }^{22}$ might also block use of constructive receipt. Any employer who enters into a deferred compensation agreement may conceivably go bankrupt before making payments under the contract, or for other reasons be unable to make payments in full. Here again, if the dangers appear to be real, constructive receipt should not be applied. If the dangers are not real, they should not prevent the use of constructive receipt to preclude tax avoidance.

In any particular case, the Treasury's decision as to whether or not the estimated payments will be received in full may, of course, prove incorrect. ${ }^{23}$ Taxes may be levied upon money which later proves uncollectable. Or taxation may be withheld from money which is later received. An amendment to the Internal Revenue Code would, however, make it possible to apply the constructive receipt doctrine to any deferred compensation agreement, and still prevent any inequities which might result should the contract in question prove more or less valuable than expected. It should empower the Commissioner to defer collection of the increased taxes resulting from inclusion of the deferred compensation until the income is actually received. When the employee has completely fulfilled his obligations under the contract, the Commissioner should total the deferred taxes and determine what proportion of the estimated payments the deferred taxes represent. That same proportion of each payment received by the beneficiary should then be turned over to the Treasury. ${ }^{24}$ Thus, the tax actually collected would depend upon the relation between the estimated payments, on the basis of which the original assessment was levied, and the payments actually received. ${ }^{25}$

21. See note 19 supra.

22. See, e.g., S. K. Jacobs, 22 B.T.A. 1166 (1931), where sums voted by corporate directors to petitioner taxpayer, although accrued on the corporation's books, were not to be paid to the taxpayer until the directors decided that the corporation's cash position would permit such payment.

23. Giving the Treasury the discretion to determine what deferred compensation agreements should be subjected to constructive receipt need cause no misgivings. "A rule need not be perfect in order to be a rule. . . . We are unwilling to proceed on the assumption that the Treasury is unable to devise a proper regulation which will afford illuminating guidance. In enacting the complex provisions on employee benefits via trusts and annuities, Congress did not despair over the Treasury's capacity to act intelligently. We, too, are not yet ready to despair." Eisenstein, supra note 2, at 420 .

24. If, for example, the deferred taxes totalled $\$ 50,000$, and payments under the contract were expected to be $\$ 100,000$, then the beneficiary would turn half of each payment received over to the Treasury.

25. The tax actually collected may still be somewhat higher or lower than would be the case if the original estimate of future receipts had been accurate. Perfection could be achieved however only by complete re-computation of the original assessments, coupled with subsequent refunds or additional levies. Such further complications do not seem warranted, since the proposed procedure will in most cases achieve substantially similar results. 